\title{
İlahiyat Fakültesi Öğrencilerinin Mizah Anlayış- larının Bazı Değişkenlere Göre İncelenmesi
}

\author{
Arş. Gör.Yusuf EMRE* \\ Gülşen ÖZGEN**
}

Atıf / @- Emre, Y.- Özgen, G. (2017). Illahiyat Fakültesi Öğrencilerinin Mizah Anlayışlarının Bazı Değişkenlere Göre Incelenmesi, Çukurova Üniversitesi Ilahiyat Fakültesi Dergisi, 17 (1), 277-298.

Öz- Mizah anlayışı ve dindarlık birbirlerinden uzak kavramlar olarak algılanmaktadır. Bundan dolayı olsa gerek ülkemizde bu iki kavram arasındaki ilişkiyi araştıran çalışma sayısı oldukça azdır. Araştırmanın amacı yüksek din öğrenimi gören öğrencilerin mizah anlayışlarını demografik değişkenler ve dindarlık algısı bağlamında incelemektir. Araştırmanın örneklemi 2014-2015 eğitimöğretim yılında Türkiye'nin 6 İlahiyat Fakültesinde öğrenim gören toplam 346 kişiden (186 kız, 160 erkek) oluşan ilahiyat lisans ve ilköğretim din kültürü ve ahlak bilgisi öğretmenliği öğrencileridir. Katıımcıların mizah anlayışları hakkında bilgi toplamak için Aslan, Alparslan, Evlice, Aslan ve Cenkseven (1999) tarafından Türkçe'ye uyarlanmış Çok Boyutlu Mizah Duygusu Ölçeği (ÇBMDÖ) kullanılmıştır. Bu araştırma sonucunda, katıımcıların mizah anlayışlarının, cinsiyete, yaşa, sosyoekonomik düzeye göre anlamlı şekilde farklılaştığı ancak sınıf düzeyine ve ikamet edilen yere göre farklılaşmadığı tespit edilmiştir. Literatürdeki birçok araştırmanın aksine araştırma bulgularına bakıldığında öğrencilerin dindarlık algısı ve mizah anlayışları arasında olumlu bir ilişki olduğu görülmüştür.

Anahtar sözcükler- Mizah anlayışı, dindarlık, mizah, çok boyutlu mizah duygusu ölçeği, Illahiyat Fakültesi

\section{$\S \S \S$}

Makalenin gelişi 15.07.2016; Yayına kabul tarihi: 19.06.2017

* Çukurova Üniversitesi, İlahiyat Fakültesi, Din Psikolojisi Anabilim Dalı, e-posta: mr_ysf@hotmail.com

** Marmara Üniversitesi Eğitim Bilimleri Enstitüsü PDR Anabilim Dalı Doktora Öğrencisi, e-posta:gulsen.topal.41@gmail.com 


\section{Giriş}

Mizah kavramı tarihsel süreç içerisinde çoğunlukla "gülmeye yol açan uyaran" olarak değerlendirilmiş, psikolojinin ayrı bir bilim dalı olarak kendini kanıtlaması ile birlikte daha ayrıntılı olarak incelenmeye başlamıştır. Söz gelimi Freud (2012) mizahı sinirsel enerjinin gülme yolu ile serbest bırakılması olarak tanımlarken, Allport (1961) sağlıklı ve olgun bir kişilik karakteri olarak betimlemiştir. Benzer şekilde Maslow (1970) ise, mizahın kendini gerçekleştirmiş bireylerdeki karakteristik özelliklerden biri olduğunu savunmuştur.

Mizahın kişiliğe yansıyan yönü olan mizah anlayışı (sense of humor), farklı ögeleri ve fonksiyonları olan bir grup özellik olarak ortaya çıkmaktadır (Thorson \& Powell, 1993a). Mizah anlayışı; gülme eğiliminin sıklığı, espri yapma ve başkalarının yaptığı esprilere gülme gibi alışılmış davranış kalıpları; mizah yaratma, başkalarını eğlendirme ve komik olayları hatırlama gibi bir yetenek; neşelilik, maskaralık gibi mizaç özelliği; mizahi öğelerin birçok çeşidiyle eğlenme gibi estetik bir tepki, mizaha ve komik insanlara olan olumlu yaklaşma gibi bir tutum; hayatı çok ciddiye almayan bir bakış ve hayatta karşılaşılan zorluklarla bir başa çıkma mekanizması olarak karşımıza çıkabilir. Mizah anlayışını oluşturan kimi ögeler birbirleriyle sıkı bir ilişki içinde olurken, kimileri olmayabilir. Sözgelimi, insanları güldürmekten hoşlanan bir kimse zorluklarla baş ederken mizahı kullanma eğiliminde olmayabilir (Martin, 2007). Mizahın bu farklı bileşenlerinden dolayı, onun kullanılması bireyden bireye farklılaşmakta ve kişinin mizaha olan eğilimine, kişiliğine, mizahi uyarana dikkat seviyesine ve zekâsına bağlı olarak değişmektedir. İnsanların mizahı kullanma tercihleri ise sahip oldukları mizah repertuvarı ile mümkün olmaktadır (Thorson \& Powell, 1993a). Bu sayede mizah çok boyutlu bir yapıya kavuşmaktadır (José, Parreira, Thorson \& Allwardt, 2007).

Thorson ve Powell (1993a)'a göre mizah duygusunun çok boyutlu yapısı içerisinde, mizah üretme ve mizahı sosyal amaçlan için kullanma, mizahı başa çıkma yolu olarak kullanma, mizah üreten kişilere karşı tutum ve mizahı değerlendirme unsurları bulunmaktadır. Kısaca belirtmek gerekirse, mizah üretme ve mizahı sosyal amaçlan için kullanma ile bireyin kendini esprili olarak tanımlaması, sosyal ortamlarda mizahı sıklıkla kullanması, mizahla sıkıntıIı durumları yumuşatabilmesi kastedilmektedir. Mizah yoluyla başa çıkma, hayatta karşılaşılan problemlerle başa çıkarken mizahi bir tutum sergileme, olayların üstesinden gülerek gelme ve bu başa çıkma tarzını değerli bulmayı içermektedir. Mizah üreten kişilere karşı tutum, esprili, şaka yapan ve insanları güldüren kişilere yönelik değer yargılarını içerir. Mizahı değerlendirme ise, mizahın duyuşsal yönüne ve işlevlerine yönelik yapılan değerlendirmeleri 
içerir. İyi bir espriden keyif duyma, mizahı rahatlatıcı bulma ve espri yapan kişilerin yeteneklerini takdir etme unsurları sayılabilir.

\section{Mizah ve Din}

Mizah ve gülme, dini gelenekte uzunca bir süre mesafeli olunması gereken, sakıncalı olabilecek konular arasında görülmüştür. Söz konusu tutumun, dini metin ve içeriklerde mizahı sınırlandıran, mizah ve gülmeye mesafeli olunması gerektiğine dair ima ve sözlerin bulunması ile ilgili olduğu söylenebilir. Söz gelimi İncil'de Hz. İsa'nın güldüğünden hiç bahsedilmemiş olması, mizahın inançlı insanların ciddiyetini ve Tanrı korkularını azaltacağının düşünülmesi gibi nedenlerle Hristiyanlık asık suratı bir din olarak algılanmaktadır (Bennett, 2011; Avcı, 2003).

Benzer şekilde, Kuran-ı Kerim'de geçen bazı ${ }^{1}$ ayetlerde alaya alma, dalga geçme ve küçük görme gibi anlamlara gelen gülmenin, din tarafından tamamen kötü bir davranış ilan edilmiş dolayısıyla yasaklanmış gibi algılanmasına neden olabilmektedir. Diğer taraftan kutsal metinlerde peygamberlerin gülmesine yer verilmemesi ve tarihsel olaylarda gülmenin alaycı, aşağılayıcı, saldırgan yönünün eleştirilmesi dindarlar nazarında önyargılara neden olabilmekte ve dinlerin mizahı ve gülmeyi tamamen yasakladığı şeklinde yorumlara yol açabilmektedir.

Saroglou (2014) din ile mizah arasında mesafe olmasının "haklı" nedenleri olduğundan bahsetmektedir. Zira mizahın doğasında toplumsal normların ihlali ve bozuma uğraması, anlamsız bir dünya ihtimali ve anlamlar üzerine oyun vardır. Aynı zamanda sürprizi, kontrol kaybını, yenilik ve belirsizliğe açıklığı içeren mizah; ahlâk, hakikat ve sevgi ile ilgili olan şeylerin zarar görmesine neden olabilmektedir. Diğer taraftan din ise anlamlı bir dünya hayatını, yaşamdaki düzeni, kontrolün gerekliliğini (Saroglou, 2002a), yenilik ve belirsizlikteki sıkıntıyı (Schwartz \& Huismans, 1995) kişiler arası ilişkilerde ahlâkî değerlere bağlı kalma sorumluluğunu (Saroglou, 2002b) vurgulamaktadır. Bu bağlamda din, otokontrolü ortadan kaldırdığı için ölçüsüz gülmeye ve mizahın din ile uyuşmayan yönlerine mesafe koymuş ve onu eleştirmiştir.

"Siz ise onlarla alay ediyordunuz. O kadar ki onlar size beni anmayı unutturdu. Onlara hep gülüyordunuz." (Mü'minûn, 110), "(Mûsâ) mucizelerimizi kendilerine getirince, bir de bakmışsın, o mucizelere gülüyorlar!" (Zuhruf, 47), "Şimdi siz gaflet içinde eğlenerek bu söze mi (Kur'an'a mı) şaşıyorsunuz, gülüyorsunuz da ağlamıyorsunuz?" (Necm, 59, 60, 61) ve "Ya da o memleketlerin halkları kuşluk vakti gülüp oynarken kendilerine azabımızın gelmesinden emin mi oldular?" (A'râf, 98) 
Collicutt ve Gray (2012) ise din ile mizah arasındaki uyuşmazlığın sebeplerini altı madde ile açıklamaktadır. Bunlardan ilki "kutsal karşısında mizahın dünyevi yönü"dür. Zira bilindiği gibi din kutsalla ilgilenir. Mizahın nesnesini dünyevileştiren, değersizleştiren yönü kutsalı zedelemektedir. Dolayısıyla dindar insanların bu tür mizah anlayışına mesafeli tutum sergilemesi beklenen bir durumdur. İkinci olarak, "inanca karşı alaycı mizah anlayışı" gösterilebilir. Birçok peygamber dini öğretilerini anlatırken, kendilerine inananlar olduğu gibi inanmayıp alay eden ve bunu mizahi unsurlar kullanarak küçük gören, değersizleştiren karşıt görüşlü insanlar da olmuştur. Böylesi durumlarda dinler, mizahın alaycı yönüne mesafeli tavır takınmışlardır. Bir diğer neden de "zarar veren tepkiler olarak muzaffer gülme ve nida" dır. İnsanları ayrım gözetmeksizin iyi davranmayı, onlarla iyi geçinmeyi ve iyi iletişim kurmayı öğütleyen dinlerin bu tür gülme biçimini hoş görmesi düşünülemez. Dolayısıyla mizahın bünyesinde bulunan üstünlük göstergesi, galibiyet sevinci ile karşısındakileri incitme gibi durumlar dinler tarafından hoş karşılanmamıştır. Dinlerin mizahta hoş görmediği bir diğer özellik de "otokontrolü bozan gülme" biçimidir. Bilindiği gibi dinler, insanların dengeli, kontrollü ve kendi davranışlarından sorumlu olduğu bir yaşam biçimini vurgulamaktadır. Gülmenin aşırı durumunda ise söz konusu denge ve kontrol zarar görmektedir. Dolayısıyla iki durum birbirinin karşısında yer almaktadır. Din ve mizah arasına mesafe koyan bir diğer neden ise "otoriteyi sarsan mizah anlayışı"dır. Mizahın en önemli özelliklerinden biri de isyan ve otoriteye başkaldırıdır. Bu özellik dinlerin otoriteye itaat ve uyumlu olma anlayışıyla çelişmektedir. Son olarak mizahın absürd ve anlamsızlıktan beslenmesi din ile ayrışma nedenlerinden biridir. Zira dinler, hayatta her şeyin bir anlamı olduğunu, tesadüfün, rastgele gerçekleşen herhangi bir şeyin olamayacağını vurgular. Kısaca din ve mizahın birbiriyle uyuşmayan yönleri, aralarında mesafe oluşmasına neden olmuştur.

Diğer taraftan, mizah ile dinin uyuşmayan yönlerinin olması ortak yönlerinin olmadığı anlamına gelmemektedir. İki kavramın azımsanmayacak ortak paydalarının olduğundan bahsedilebilir. Her şeyden önce din ve mizah insan hayatının iki önemli gerçeğidir. Yaşamın tamamında olmasa bile birçok yönünde etkili olmak dinin en önemli ideallerindendir. Mizah ise hayatın birçok alanında, kişiler arası ve sosyal ilişkilerin düzenlenmesinde (Cann, Norman, Welbourne \& Calhoun, 2008) yaşam doyumunu artırmada (Ay, Gökler ve Koçak, 2013) kendisine yer bulabilmektedir. Ayrıca mizahın, başa çıkma fonksiyonu sayesinde stresli yaşam olayları karşısında daha yapıcı bir görev üstlendiği söylenebilir (Kuiper \& Nicholl, 2004; Abel, 2002; Szabo, 2003). Benzer bir şekilde dinî argümanlar da kişinin anlam veremediği ve çıkmaza girdiği 
durumlarda alternatif anlamlar sunarak dinî başa çıkma ile bireyin psikolojisine katkı sağlayabilmektedir (Saroglou, 2014; Koenig, George \& Titus, 2004; Park, 2005; Ayten, Göcen, Sevinç ve Öztürk, 2002; Özgen, 2014).

Mizah-din ilişkisinde mizah, dinî konularda kutsal değerleri profanlaştırmadığı ve küçük düşürmediği sürece ikisi arasında normal bir etkileşimden bahsedilebilir. Mizah ve din, başa çıkma örneğinde olduğu gibi birçok ortak amaca hizmet edebilecek niteliklere sahiptir (Capps, 2006). Bunu yaparken birbirlerinden de faydalandıklarını söylemek yanlış olmaz. Zira dinî literatürde çok sayıda mizahî öğenin olduğundan bahsedilebilir (bkz. Doğan, 2004; Doğan, 2006; Marzolph, 2000). Söz gelimi bazı yeni dini hareketlerde doğu ve antik yunan dinlerindekine benzeyen mizah ifadelerine ve hatta ritüelleşmiş kutsal kahkahaya rastlamak mümkündür (Saroglou, 2014). Bu bağlamda mizah - dindarlık ilişkisinin çok yönlü ve çok boyutlu olarak düşünülmeye ve değerlendirilmeye intiyacı olduğu görülmektedir.

Mizah ve din üzerine yapılan uygulamalı çalışmalara (Saroglou, 2002a; Saroglou \& Anciaux, 2004) bakıldığında, dindar bireylerin mizaha karşı olumlu bir tutumda olmadıkları ve dindar olmayanlara göre mizahı daha az kullandıklarına yönelik bulgular elde edilmiştir. Bu durum araştırmacılar tarafından mizahın saçmalığı ortaya çıkarması, cinsellik, hazcııık ve saldırganlık dürtüleri içermesi gibi dinî ve ahlâkî kurallara ters düşen özellikleri nedeniyle dindarlar tarafından cazip bulunmamış olabileceği şeklinde yorumlanmıştır. Batı örnekleminde yapılan bu çalışmaların karşısında ülkemizde dindar bireylerin mizah anlayışlarının nasıl olduğu sorusu çalışmamızın temel problemini oluşturmaktadır. Yükseköğretim seviyesinde din eğitimi alan ve nispeten dindar olarak kabul edilebilecek ilahiyat fakültesi öğrencilerinin mizah anlayışı hakkında fikir edinmeyi amaçlayan bu çalışma, ülkemizdeki farklı bölge ve üniversitelerdeki öğrencilere ulaşarak genel bir fikir vermek istemektedir.

\section{Cevap Aranan Sorular}

1. Yüksek din öğrenimi gören öğrencilerin, mizah anlayışı alt boyutlarına yaklaşımları nasıldır? Katılımcılar, mizah anlayışının hangi alt boyutuna daha fazla, hangisine daha az önem veriyorlar? Illahiyat lisans ve ilköğretim din kültürü ve ahlak bilgisi (IDKAB) öğretmenliği bölümü öğrencileri arasında mizah anlayışı alt boyutlarında anlamlı bir farklılık var mı?

2. Öğrencilerin dindarlık algıları ile mizah anlayışı alt boyutları arasında anlamlılık seviyesine ulaşan ilişkiler var mıdır? 
3. İlahiyat Fakültesi öğrencilerinin mizah anlayışı demografik değişkenler açısından farklılaşmakta mıdır?

\section{Yöntem}

\section{Araştırmanın Modeli}

$\mathrm{Bu}$ araştırma, yüksek din öğrenimi (İlahiyat lisans ve İDKAB öğretmenliği bölümü) gören öğrencilerin mizah anlayışına ilişkin algılarını belirlemeye yönelik tarama modelinde betimsel bir çalışmadır. Araştırma bulguları SPSS 20 programı ile işlenmiş; Bağımsız Gruplar t-Testi, Pearson Çarpım Moment Korelasyon Analizi ve Tek Yönlü Varyans Analizi istatistik teknikleri kullanılarak Mizah Anlayışı alt boyutları ile Dindarlık Algısı ve demografik değişkenler arasındaki ilişki ve farklılıklar analiz edilmiştir.

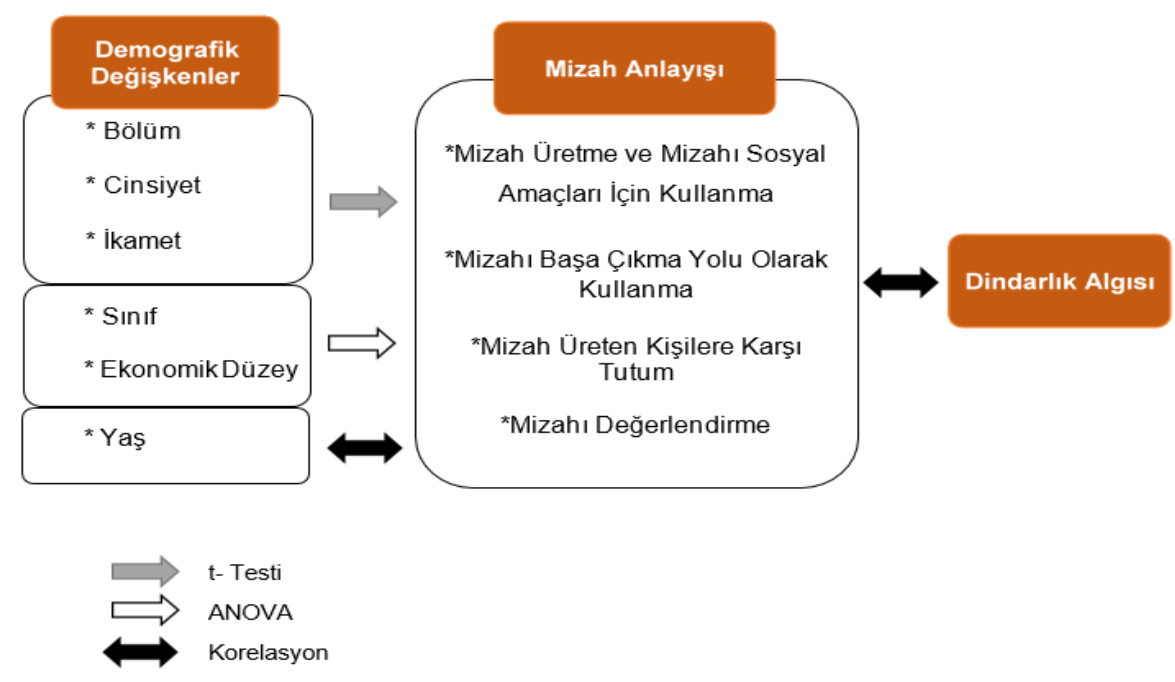

Şekil 1. Araştırmanın Modeli

\section{Örneklem}

2014-2015 eğitim-öğretim yılında yapılan bu çalışmaya Marmara, İstanbul, Erzurum, Çukurova, Dokuz Eylül ve Harran Üniversitesi İlahiyat Fakültesi öğrencilerinden tesadüfi yöntemle seçilen 346 kişi katılmıştır. Bunlardan 186'sı (\% 53,8) kız, 160'ı (\% 46,2) ise erkektir. Katılımcıların yaş aralığı 17-38, yaş ortalaması ise 22.22'dir. Araştırmaya katılan öğrencilerin 202'si (\% 58,4) İlahiyat Lisans bölümü, 144'ü (\% 41,6) ise İDKAB öğretmenliği bölümünde eğitim görmektedirler. Sınıflarına göre dağılıma bakıldığında ise 1. sınıftan 71 
(\% 20,5), 2. sınıftan 63 (\% 18,2), 3. sınıftan 112 (\% 32,4) ve 4. sınıftan 97 (\% $28,0)$ kişinin katıldığı görülmektedir. Ayrıca öğrencilerin 294'ü (\% 85,0) kentte (büyükşehir, il, ilçe), 52'si (\% 15,0) kırda (kasaba, köy) ikamet ettiğini belirtmiştir.

\section{Veri Toplama Araçları}

Kişisel Bilgi Formu: Kişisel bilgi formunda katılımcılara cinsiyet, yaş, aile gelir durumu, yaşamın çoğunun geçirildiği yer, akademik başarı durumu, okuduğu bölüm ve sınıf gibi sorular sorulmuştur. Ayrıca, araştırmaya katılanların dindarlık algısını belirlemek amacıyla, katılımcılara 6'lı likert tipi (1 = Dinle bir ilgim yok, 6 = Çok dindarım) bir ölçek uygulanmıştır.

Çok Boyutlu Mizah Duygusu Ölçeği (ÇBMDÖ): Thorson ve Powell (1993a) tarafından geliştirilmiş; Aslan, Alparslan, Evlice, Aslan ve Cenkseven (1999) tarafından Türkçe'ye uyarlanmış 24 ifadeden oluşan 5'li likert tipi bir ölçektir. Ölçeğin ismi “Çok Boyutlu Mizah Duygusu” olarak Türkçe'ye kazandırılmış olmasına karşın "sense of humor" ifadesinin "mizah anlayışı" olarak çevrildiğinde anlatılmak isteneni daha iyi karşılayacağı düşünüldüğü için makalede mizah duygusu yerine mizah anlayışı ifadesi kullanılmıştır. Ölçeğin maddeleri, (1) "bana hiç uygun değil" ve (5) "bana tamamıla uygun" arasında değişen 5'li likert tarzda yanıtlanmaktadır. Olumsuz ifadeler içeren maddeler tersten, 5-1 olarak puanlanmıştır. Ölçekten alınabilecek en düşük puan 24, en yüksek puan 120'dir. Ana bileşenler ve Oblimin rotasyonu yöntemleri kullanılarak yapılan faktör analizi sonucu, toplam varyansın \%54.8'ini açıklayabilen ve özdeğeri 1'in üzerinde olan ölçeğin dört alt boyutunun olduğu doğrulanmıştır. Birinci alt boyut, mizah üretme ve mizahı sosyal amaçlan için kullanma (M.Ü.), ikinci alt boyut mizahı başa çıkma yolu olarak kullanma (M.B.K), üçüncü alt boyut mizah üreten kişilere karşı tutum (M.T.), dördüncü alt boyut ise mizahı değerlendirme (M.D.)dir. "Mizah üreten insanları takdir ederim." ifadesi birden fazla faktöre yüklenme yaptığı için analize alınmamıştır. Ölçeğin Cronbach alfa katsayısı 0. 88'dir.

\section{Bulgular}

\section{Mizah Anlayışı ve Dindarlıkla İlgili Bulgular}

İlahiyat Fakültesi öğrencilerinin mizah anlayışı alt boyutlarına verdikleri önem sırası ortalamalar üzerinden Şekil 2'de gösterilmiştir. 


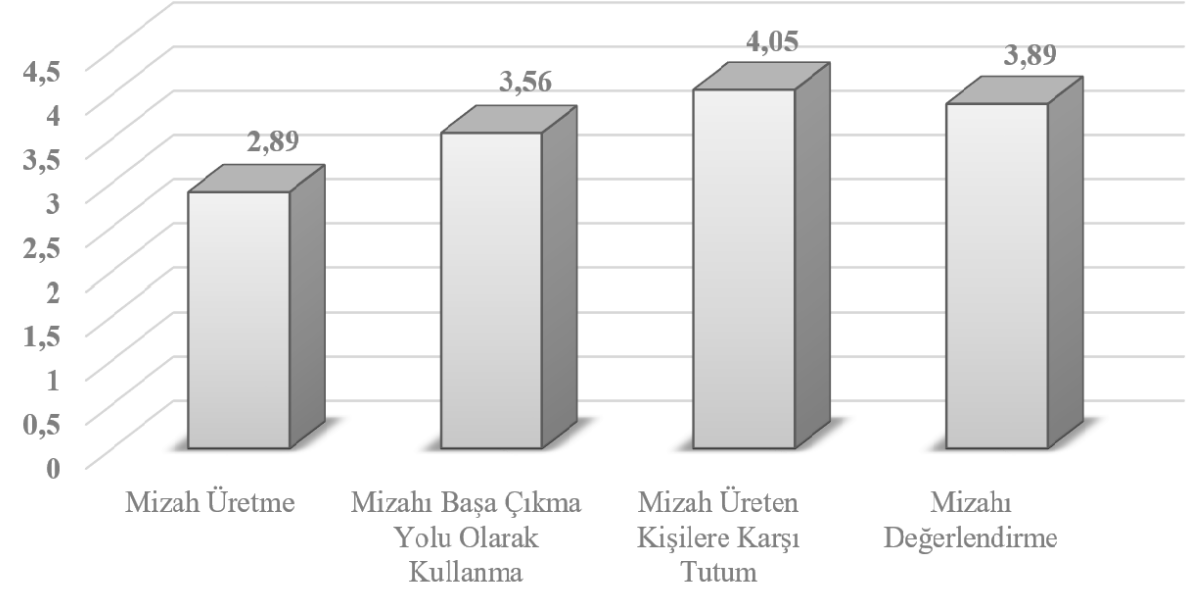

Şekil 2. Mizah Anlayışı Alt Boyutları Önem Sırası (Ort.)

Ortalamalara bakılacak olursa, mizah üreten kişilere karşı tutum $\left({ }^{\bar{x}}=4.05\right)$, mizahı değerlendirme $\left({ }^{\bar{x}}=3.89\right)$, mizahı başa çıkma yolu olarak kullanma $\left({ }^{\bar{x}}=3.56\right)$ ve mizah üretme $\left({ }^{\bar{x}}=2.89\right)$ şeklinde bir sıralamanın ortaya çıktığı görülecektir. Mizah üreten kişilere karşı tutum en çok önemsenen boyut olarak ön plana çıkarken, mizah üretme boyutunun son sırada kalması ise ilgi çekici bir sonuç olmuştur. Araştırmada cevap aranan sorulardan olan "ilahiyat lisans ve İDKAB öğretmenliği bölümü öğrencileri arasında mizah anlayışı alt boyutlarında anlamlı bir farklılık var mı?" ifadesine ilişkin yapılan bağımsız gruplar t-testi analizi sonuçları Tablo 1'de sunulmuştur.

Tablo 1

Mizah Anlayışı Alt Boyutlarının Bölüme Göre Analizi (t-testi)

\begin{tabular}{llllllll}
\hline Alt Boyut & Bölüm & $\mathbf{N}$ & $\overline{\boldsymbol{X}}$ & $\mathbf{S}$ & $\mathbf{t}$ & $\mathbf{s d}$ & $\mathbf{p}$ \\
\hline & İlahiyat & 202 & 2.77 & .90 & -2.848 & 344 & .005 \\
M.Ü. & DKAB & 144 & 3.04 & .84 & & & \\
\hline & İlahiyat & 202 & 3.50 & .69 & -1.478 & 344 & .140 \\
M.B.K. & DKAB & 144 & 3.62 & .76 & & & \\
\hline & İlahiyat & 202 & 4.06 & .62 & .624 & 344 & .533 \\
M.T. & DKAB & 144 & 4.01 & .67 & & & \\
\hline & İlahiyat & 202 & 3.83 & .82 & -1.597 & 344 & .111 \\
M.D. & DKAB & 144 & 3.97 & .86 & & & \\
\hline
\end{tabular}


Tablo-1'de görüldüğü gibi İDKAB bölümü öğrencileri ortalamalar üzerinden ilahiyat lisans bölümü öğrencilerinden mizah üretme, mizahı başa çıkma yolu olarak kullanma ve mizahı değerlendirme alt boyutlarından daha fazla puan alırken, mizah üreten kişilere karşı tutum alt boyutunda tersi durum ortaya çıkmıştır. Bu sonuçlar içerisinde anlamlılık seviyesine ulaşabilen tek farklılık mizah üretme alt boyutunda görülmüştür [t(346): -2.848, $\mathrm{p}<0.05]$. Buna göre İDKAB bölümü öğrencilerinin İlahiyat lisans bölümü öğrencilerine göre mizah konusunda daha üretken olduklarını söylemek mümkündür. Dindarlık algısı ile mizah anlayışı alt boyutları arasında anlamlılık seviyesine ulaşan ilişkiler olup olmadığını belirlemek için yapılan Pearson Korelasyon analiz sonuçları Tablo 2'de sunulmuştur.

Tablo 2

Dindarlık Algısı ile Mizah Anlayışı Alt Boyutları Arasındaki Illişkiye Dair Pearson Korelasyon Sonuçları

\begin{tabular}{|c|c|c|c|}
\hline \multirow{2}{*}{$\begin{array}{l}\text { Mizah Anlayışı } \\
\text { Alt Boyutları }\end{array}$} & \multicolumn{3}{|c|}{ Dindarlık Algısı } \\
\hline & $\mathbf{N}$ & $\mathbf{r}$ & $\mathbf{p}$ \\
\hline M.Ü. & 334 & .031 & .578 \\
\hline M.B.K. & 334 & .000 & .993 \\
\hline M.T. & 334 & $.113^{*}$ & .039 \\
\hline M.D. & 334 & .025 & .648 \\
\hline
\end{tabular}

${ }^{*} \mathrm{p}<.05$

Tablo 2'deki sonuçlara göre dindarlık algısı ile mizah üretme ( $\mathrm{r}=.031$, $\mathrm{p}>$.05), mizahı başa çıkma yolu olarak kullanma $(\mathrm{r}=.000, \mathrm{p}>.05)$ ve mizahı değerlendirme $(r=.025, p>.05)$ alt boyutları arasında anlamlılık seviyesine ulaşan ilişki söz konusu değildir. Dindarlık algısı ile mizah üreten kişilere karşı tutum $(r=.113, p<.05)$ arasında ise pozitif yönde anlamlı ilişki vardır. Diğer bir ifadeyle, dindarlık algısına verilen puanlar arttıkça mizaha ve mizah yapanlara karşı tutum puanları da artmıştır.

\section{Mizah Anlayışı ve Demografik Değişkenlerle İlgili Bulgular}

Öğrencilerin Çok Boyutlu Mizah Duygusu Ölçeği'nden almış oldukları toplam ortalama puanlarının cinsiyete göre anlamlı bir fark oluşturup oluşturmadığını bulmak için yapılan Bağımsız Gruplar t-Testi sonuçları Tablo-3'te gösterilmiştir. 
Tablo 3

Mizah Anlayışı Alt Boyutlarının Cinsiyete Göre Analizi (t-testi)

\begin{tabular}{llllllll}
\hline Alt Boyut & Cinsiyet & $\mathbf{N}$ & $\overline{\boldsymbol{X}}$ & $\mathbf{S}$ & $\mathbf{t}$ & $\mathbf{s d}$ & $\mathbf{p}$ \\
\hline & Kız & 186 & 2.77 & .88 & -2.657 & 344 & .008 \\
M.Ü. & Erkek & 160 & 3.02 & .87 & & & \\
\hline & Kız & 186 & 3.70 & .72 & 4.160 & 344 & .000 \\
M.B.K. & Erkek & 160 & 3.38 & .69 & & & \\
\hline & Kız & 186 & 4.15 & .58 & 3.515 & 344 & .001 \\
M.T. & Erkek & 160 & 3.91 & .69 & & & \\
\hline & Kız & 186 & 3.99 & .83 & 2.460 & 344 & .014 \\
M.D. & Erkek & 160 & 3.77 & .84 & & & \\
\hline
\end{tabular}

Tablo 3'te görüldüğü gibi kızların mizah üretme alt boyutuna ilişkin aritmetik ortalama puanı 2.77 iken, erkeklerin aritmetik ortalama puanı 3.02'dir. Yapılan t-testi analizi sonucunda öğrencilerin mizah üretme alt boyutunda $\left(\mathrm{t}_{(344)=}=-2.657, \mathrm{p}<.05\right)$ cinsiyete göre anlamlı farklılaşmanın olduğu, erkek öğrencilerin kızlara göre mizah üretme boyutundan daha fazla puan aldığı saptanmıştır. Tablo 3'e tekrar bakıldığında, mizahı başa çıkma yolu olarak kullanma $\left(\mathrm{t}_{(344)}=4.160, \mathrm{p}<.05\right)$, mizahı üreten kişilere karşı tutum $\left(\mathrm{t}_{(344)}=3.515\right.$, $\mathrm{p}<.05)$ ve mizahı değerlendirme $\left(\mathrm{t}_{(344)}=2.460, \mathrm{p}<.05\right)$ alt boyutlarında ise $\mathrm{kız}$ öğrencilerin erkek öğrencilere göre daha fazla puan aldıkları ve bu farkın anlamlılık seviyesinde olduğu görülmektedir.

Tablo 4

Mizah Anlayışı Alt Boyutlarının Ikamete Göre Analizi (t-testi)

\begin{tabular}{llllllll}
\hline Alt Boyut & İkamet & $\mathbf{N}$ & $\overline{\boldsymbol{X}}$ & $\mathbf{S}$ & $\mathbf{t}$ & $\mathbf{s d}$ & $\mathbf{p}$ \\
\hline & Kent & 294 & 2.89 & .89 & .137 & 344 & .891 \\
M.Ü. & Kır & 52 & 2.87 & .85 & & & \\
\hline & Kent & 294 & 3.57 & .73 & 1.315 & 344 & .189 \\
M.B.K. & Kır & 52 & 3.43 & .69 & & & \\
\hline & Kent & 294 & 4.06 & .62 & 1.364 & 344 & .177 \\
M.T. & Kır & 52 & 3.91 & .75 & & & \\
\hline & Kent & 294 & 3.91 & .84 & 1.291 & 344 & .198 \\
M.D. & Kır & 52 & 3.75 & .86 & & & \\
\hline
\end{tabular}


Mizah anlayışı alt boyutlarına etkisi sorgulanan bir diğer değişken öğrencilerin ikamet ettiği yerin özellikleridir. İkamet edilen yerin özelliğine göre Mizah Anlayışı alt boyutlarının tamamında kentte yaşayanlar kırda yaşayanlara göre daha fazla puan almış, Tablo 4'te sunulan veriler, farklılıkların anlamlı olduğunu göstermiştir. Ancak, bağımsız gruplar t-testi analiz sonuçları bu farklılıkların [ mizah üretme $\left(\mathrm{t}_{(344)}=.137, \mathrm{p}>.05\right)$, mizahı başa çıkma yolu ola-

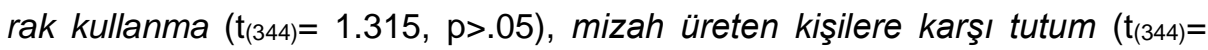
$1.364, \mathrm{p}>.05)$ ve mizahı değerlendirme $\left(\mathrm{t}_{(344)}=1.291, \mathrm{p}>.05\right)$ ] alt boyutlarında anlamlılık seviyesine ulaşmadığını söylemektedir.

Tablo 5

Öğrencilerin Sosyoekonomik Durumlarına İlişkin Tek Yönlü Varyans Analizi (ANOVA) Sonuçları

\begin{tabular}{|c|c|c|c|c|c|c|c|}
\hline $\begin{array}{l}\text { Mizah } \\
\text { Anla- } \\
\text { yışı } \\
\text { Alt } \\
\text { Boyu- } \\
\text { tu } \\
\end{array}$ & $\begin{array}{l}\text { Ekono- } \\
\text { mik Du- } \\
\text { rum }\end{array}$ & $\mathbf{N}$ & $\overline{\boldsymbol{X}}$ & $\mathbf{S}$ & $\mathbf{F}$ & $\mathbf{p}$ & Hochberg's GT2 \\
\hline \multirow{4}{*}{ M.Ü. } & Alt & 36 & 2.77 & .91 & & & \multirow{4}{*}{$\begin{array}{l}\text { Üst - Orta. } \\
\text { Üst - Alt }\end{array}$} \\
\hline & Orta & 254 & 2.82 & .86 & 5.652 & .004 & \\
\hline & Üst & 56 & 3.24 & .89 & & & \\
\hline & Toplam & 346 & 2.88 & .88 & & & \\
\hline \multirow{4}{*}{ M.B.K. } & Alt & 36 & 3.55 & .78 & \multirow{4}{*}{.922} & \multirow{4}{*}{.399} & \\
\hline & Orta & 254 & 3.53 & .69 & & & \\
\hline & Üst & 56 & 3.67 & .82 & & & \\
\hline & Toplam & 346 & 3.55 & .72 & & & \\
\hline \multirow{4}{*}{ M.T. } & Alt & 36 & 3.96 & .74 & \multirow{4}{*}{.365} & \multirow{4}{*}{.694} & \\
\hline & Orta & 254 & 4.05 & .63 & & & \\
\hline & Üst & 56 & 4.03 & .67 & & & \\
\hline & Toplam & 346 & 4.04 & .65 & & & \\
\hline \multirow{4}{*}{ M.D. } & Alt & 36 & 3.98 & .89 & \multirow{4}{*}{2.189} & \multirow{4}{*}{.114} & \\
\hline & Orta & 254 & 3.83 & .86 & & & \\
\hline & Üst & 56 & 4.08 & .72 & & & \\
\hline & Toplam & 346 & 3.89 & .84 & & & \\
\hline
\end{tabular}


Tablo-5'de görüldüğü gibi Tek Yönlü Varyans Analizi (ANOVA) sonuçlarında İlahiyat Fakültesi öğrencilerinin mizah üretme alt boyutunda ekonomik duruma göre anlamlı bir fark bulunmuştur $\left[F_{(2-343)}=5.652, p<.05\right]$. Farkın hangi gruplar arasında olduğunu bulmak için grup sayıları arasındaki farkın büyük olduğu durumlarda daha sağlıklı sonuçlar veren Hochberg's GT2 testi kullanılmıştır. Hochberg's GT2 testinin sonuçlarına göre, sosyoekonomik bakımından üst düzeyde olduklarını ifade eden öğrencilerin $\left({ }^{\bar{x}}=3.24\right)$ mizah üretme puanlarının, orta düzeyde olan $(\bar{x}=2.82)$ ve alt düzeyde olan öğrencilerden $\left.\overline{\bar{x}}_{\bar{x}}=2.77\right)$ daha yüksek olduğu saptanmıştır.

Tablo 5'e tekrar bakıldığında, İlahiyat Fakültesi öğrencilerinin mizahı başa çıkma yolu olarak kullanma $\left[\mathrm{F}_{(2-343)}=.922, \mathrm{p}>.05\right]$, mizah üreten kişilere karşı tutum $\left[\mathrm{F}_{(2-343)}=.365, \mathrm{p}>.05\right]$ ve mizahı değerlendirme $\left[\mathrm{F}_{(2-343)}=2.189\right.$, $p>.05$ ] alt boyutlarında sosyoekonomik duruma göre anlamlı bir fark olmadığı görülmektedir.

Öğrencilerin öğrenim gördükleri sınıfa göre mizah anlayışı alt boyutlarında anlamlı farklılık olup olmadığını tespit etmek için yapılan ANOVA sonuçları Tablo 6'da sunulmuştur.

Tablo 6

Öğrencilerin Sınıflarına Illişkin Tek Yönlü Varyans Analizi (ANOVA) Sonuçları

\begin{tabular}{lllllll}
\hline $\begin{array}{l}\text { Mizah Anlayışı } \\
\text { Alt Boyutu }\end{array}$ & Sınıf & $\mathbf{N}$ & $\overline{\boldsymbol{X}}$ & $\mathbf{S}$ & $\mathbf{F}$ & $\mathbf{p}$ \\
\hline & 1 & 71 & 2.82 & .88 & & \\
M.Ü. & 2 & 63 & 3.06 & .83 & & \\
& 3 & 112 & 2.92 & .89 & 1.949 & .122 \\
& 4 & 97 & 2.74 & .87 & & \\
& Toplam & 343 & 2.87 & .88 & & \\
M.B.K & 1 & 71 & 3.42 & .73 & & \\
& 2 & 63 & 3.59 & .73 & & \\
& 3 & 112 & 3.59 & .72 & .874 & .455 \\
& 4 & 97 & 3.55 & .70 & & \\
& Toplam & 343 & 3.54 & .72 & & \\
M.T. & 1 & 71 & 4.05 & .64 & & \\
& 2 & 63 & 3.95 & .66 & & \\
& 3 & 112 & 4.05 & .67 & .455 & .714 \\
& 4 & 97 & 4.07 & .62 & & \\
\hline
\end{tabular}




\begin{tabular}{lllllll}
\hline & 1 & 71 & 3.74 & .88 & & \\
M.D. & 2 & 63 & 3.83 & .97 & & \\
& 3 & 112 & 3.99 & .78 & 1.352 & .257 \\
& 4 & 97 & 3.88 & .79 & & \\
& Toplam & 343 & 3.88 & .84 & & \\
\hline
\end{tabular}

Tablo-6'da görüldüğü gibi tek faktörlü varyans analizi sonuçlarında İlahiyat Fakültesi öğrencilerinin mizah üretme $\left[\mathrm{F}_{(5-337)}=1.949, \mathrm{p}>.05\right]$, mizahı başa çıkma yolu olarak kullanma $\left[\mathrm{F}_{(5-337)}=.874, \mathrm{p}>.05\right]$, mizah üreten kişilere karşı tutum $\left[\mathrm{F}_{(2-343)}=.455, \mathrm{p}>.05\right]$ ve mizahı değerlendirme $\left[\mathrm{F}_{(2-343)}=1.352\right.$, p>.05] alt boyutlarında sınıfa göre anlamlı bir fark ortaya çıkmamıştır.

Yaş ile mizah anlayışı alt boyutları arasında anlamlılık seviyesine ulaşan ilişkiler olup olmadığını belirlemek için yapılan Pearson Korelasyon analiz sonuçları Tablo 7'de gösterilmiştir.

Tablo 7

Yaş ile Mizah Anlayışı Alt Boyutları Arasındaki Ilişskiye Dair Pearson Korelasyon Sonuçları

\begin{tabular}{|c|c|c|c|c|}
\hline \multirow{2}{*}{$\begin{array}{l}\text { Mizah Anlayışı } \\
\text { Alt Boyutları }\end{array}$} & & \multicolumn{3}{|c|}{ Yaş } \\
\hline & & $\mathbf{N}$ & $r$ & $p$ \\
\hline M.Ü. & 335 & -.094 & & .086 \\
\hline M.B.K. & 335 & $-.115^{*}$ & & .036 \\
\hline M.T. & 335 & -.034 & & .533 \\
\hline M.D. & 335 & -.085 & & .121 \\
\hline
\end{tabular}

Tablo 7'deki sonuçlara bakıldığında, yaş değişkeninin mizah anlayışı alt boyutlarının tamamı ile negatif yönde korelasyona sahip olduğu görülmektedir. Yani yaş arttıkça mizahla ilgili maddelere verilen puanlar düşmektedir. Ancak Pearson Korelasyon sonuçlarına göre, yaş ile mizah üretme ( $r=-.094$, $\mathrm{p}>$.05), mizah üreten kişilere karşı tutum ( $\mathrm{r}=-.034, \mathrm{p}>.05)$ ve mizahı değerlendirme $(r=-.085, p>.05)$ alt boyutları arasındaki ilişkiler anlamlılık seviyesinde değildir. Yalnızca mizahı başa çıkma yolu olarak kullanma $(r=-.115, p<.05)$ arasındaki korelasyon anlamlılık seviyesine ulaşmıştır. 


\section{Tartışma ve Sonuç}

Araştırma bulgularına göre, İlahiyat Fakültesi öğrencilerinin mizah anlayışı alt boyutlarına verdikleri önem düzeyleri, mizah üreten kişilere karşı tutum, mizahı değerlendirme, mizahı başa çıkma yolu olarak kullanma ve mizah üretme(ve mizahı sosyal amaçları için kullanma) şeklinde bir sıralama ortaya çıkarmıştır (Şekil-2). Karikatürden hoşlanma, mizah yapılan ortamlardan keyif almayı ve şakaların insanları neşelendiren etkinlikler olduğunu içeren mizah üreten kişilere karşı tutum boyutunun diğer alt boyutların önüne geçmesi İlahiyat Fakültesi öğrencilerinin mizaha ve mizah yapan kişilere karşı olumlu tutumunu göstermektedir. Bunun yanı sıra; nüktedan olarak tanınmak, insanları güldürüp eğlendirebilme, mizahta orijinal olma ve sıradan şeyleri komik şekilde anlatabilme gibi mizahı etkin biçimde kullanma anlamlarına gelen mizah üretme ve mizahı sosyal amaçlar için kullanma alt boyutunun son sırada olması, İlahiyat Fakültesi öğrencilerinin mizah üretme hususunda çekingen bir tavır sergiledikleri şeklinde yorumlanabilir. Sıralamadaki diğer alt boyutlara dikkat edildiğinde mizah hakkındaki onaylayıcı ve takdir edici maddeleri barındıran mizahı değerlendirme boyutu, mizahı stres ve problemlere karşı başa çıkma yöntemi olarak kullanma boyutundan daha fazla önemsenmiştir. Bu durum, ilahiyat fakültesi öğrencilerinin mizah hakkında olumlu tutumlara sahip olduklarına, mizahı onayladıkları ve mizahi içeriklerin hayatlarında bulunmasından mutluluk duyduklarını ancak mizahı etkin biçimde kullanma ve mizah üretme hususunda nispeten çekingen olduklarına işaret etmektedir. Söz konusu sonuç, literatürde mevcut olan dindarlığın mizah üretmeye sınırlandırıcı etkide bulunduğuna yönelik görüşleri doğrular nitelikte bir veri olarak karşımıza çıkmaktadır. Diğer taraftan Saroglou ve Scariot'un (2002d) Belçika Louvain Katolik Üniversitesi öğrencileri örnekleminde yaptığı araştırmada dindarlık ile mizah yaratıcılığı arasında negatif yönde anlamlı ilişkiler tespit etmesi de çalışmamızla uyumlu bir sonuç olmuştur. Kültürümüzde ağır ol molla desinler atasözünün ciddi ve vakarlı durmanın dindarlığın bir gerekliliği olduğunu ifade etmesi tesadüf değildir.

İlahiyat lisans ile IDKAB bölümü öğrencileri arasında mizah anlayışı alt boyutlarından mizah üretme, bir diğer deyişle sosyal ortamda mizahı kullanma açısından anlamlılığa ulaşan farklılıklar tespit edilmiştir (Tablo-1). IDKAB bölümü öğrencileri ilahiyat lisans bölümü öğrencilerine göre mizah üretme hususunda daha fazla puan almışlardır. Bu durum yoğun din dersi alan ilahiyat lisans bölümü öğrencilerinin, din ile mizahın birbiriyle uyuşmayan özelliklerinin etkisini İDKA bölümü öğrencilerine göre daha fazla hissetmiş olması ile açıklanabilir. Zira dünya hayatının anlamlılığını, yaşamdaki düzeni, 
kişiler arası ilişkilerde sorumluluğu vurgulayan din; toplumsal normların ihlalinden, anlam bozumundan, kişilerarası ilişkileri zora sokabilecek (küfürlü, müstehcen içerikli, agresif ve alay içeren) mizahi öğelerden, ölçüsüz gülme ve sürprizlerden beslenen mizahı sınırlandırmak ister (Doğan, 2004; Altınay, 2004). Kısaca, dinin mizahı kendi ölçüsüne göre sınırlandırması yoğun din eğitimi alan öğrencilerin mizah üretkenliği hususunda daha çekingen olmasını etkilemiş olabilir. Diğer taraftan, İDKAB bölümü öğrencilerinin aldığı sınıf yönetimi ve eğitim psikolojisi gibi dersler aracılığıyla mizahın ders başarısını ve öğrenilen bilgilerin kalıcılığını olumlu yönde etkilediğine (Savaş, 2003; Çelik, 2014; Şahin, 2010) yönelik formasyona sahip olmaları, onların, ilahiyat lisans öğrencilerine nispetle mizaha daha fazla önem verdiği sonucunu açıklayabilir.

Dindarlık algısı ile mizah anlayışı alt boyutları arasındaki ilişkilere bakıldığında yalnızca mizah üreten kişilere karşı tutum boyutu arasında pozitif yönde anlamlı bir korelasyon bulunmuştur (Tablo-2). Bu sonuç, dindarlık algısından yüksek puan alan öğrencilerin, mizaha ve mizahla ilgilenen kişilere karşı olumlu bir tutum içinde oldukları; şaka yapmayı ve karikatürleri insanların neşelenmesine katkı sağlayıcı etkisini onayladıkları; fıkra anlatan espri yapan kişilerin yanında olmaktan mutluluk duydukları ve şaka yapılan ortamlarda kendilerini rahat hissettikleri anlamına gelmektedir. Genel bir değerlendirme yapılacak olursa, din ile mizahın uyuşmayan yönleri mizah üretkenliğini sınırlandırsa da öğrencilerin mizaha tamamen olumsuz bakmasına neden olmamaktadır. Bunda dinin mizah ile ortak amaçları ve fonksiyonlarının da bulunmasının (sorunlarla başa çıkma ve iletişimi kolaylaştırma gibi), mizahın son yıllarda mutlu ve sağlıklı olmayla ilişkilendirilmesi ve nitelikli insan özelliği olarak ön plana çıkmasının etkileri olabilir. Nitekim son yıllarda pozitif psikoloji araştırmalarında mizah, 24 karakter özelliği arasında sayılmaktadır (Akın ve Bilgin, 2015).

Mizah anlayışı ile cinsiyet arasında anlamlı farklılığın olup olmadığına bakıldığında, Mizah üretme boyutunda erkeklerin kızlara göre; mizahı başa çıkma yolu olarak kullanma, mizah üreten kişilere karşı tutum ve mizahı değerlendirme boyutunda ise kızların erkeklere nispetle daha fazla puan aldıkları ve bu puan farkının anlamlılık seviyesine ulaştığı tespit edilmiştir (Tablo-3). Bu sonuçlara göre erkek öğrencilerin, kız öğrencilere göre fıkra anlatma, esprili ve muzip sözler üretme, şaka yapma hususunda daha istekli ve etkin oldukları söylenebilir. Diğer taraftan kız öğrenciler ise mizah üretmeyi tercih etmeseler de mizahı günlük sıkıntı ve stresten uzaklaşma adına kullanma, mizahı onaylama, mizah yapan kişilere ilgi gösterme ve mizahi unsurları takdir etme gibi konularda erkek öğrencilerden farklılaştıkları araştırma bulgularınca destek-

ÇÜiFD, 2017, cilt: 17, sayı: 1, ss. 277-298 
lenmektedir. (Martin, Puhlik-Doris, Larsen, Gray \& Weir, 2003; Thorson \& Powell, 1993b). Söz konusu farklılıkları toplumun cinsiyete yüklediği anlam ve onlardan beklentileri ile açıklamak mümkündür. Zira mizah üretmek, gülmek ve güldürmek özellikle kızlar açısından düşünüldüğünde geleneksel rol beklentileri ile uyuşmayabilir. Ancak erkekler bu konuda daha rahat yetiştirilirler. Elbette bu durumu genellemek (kültürel özellikler taşıdığı için) mümkün değildir. Çünkü kültürlerarası araştırma sonuçları genellikle birbirinden farklı bulgulara işaret etmektedir. Boyle ve Joss-Reid'in (2004) Avusturalyalı öğrencilerde, Jose ve arkadaşlarının (2007) Portekiz örnekleminde, Esterhuyse ve arkadaşlarının (2013) Güney Afrikalı ergenlerde ve Tariq ve Khan'ın (2013) Pakistanlı lise ve üniversite öğrencileri örnekleminde yaptığı araştırmalarda mizah anlayışı ile cinsiyet arasında anlamlı farklılık tespit edilememişsir. Diğer taraftan Madhan ve arkadaşlarının (2013) Hindistan'da diş hekimliği fakültesi öğrencileri ile yaptığı araştırmada ise mizah anlayışı hususunda erkek öğrenciler kız öğrencilere göre daha puan almışlar, aradaki bu fark anlamlılık seviyesine ulaşmıştır. Benzer şekilde Saroglou (2002c)'nun mizah yaratıcılığı hususunda erkeklerin karşı cinse göre daha çok puan aldığı çalışması mevcuttur.

Öğrencilerin ikamet ettikleri yerin özelliğine göre mizah anlayışı alt boyutlarında anlamlı farklılık ortaya çıkmamıştır (Tablo-4). Şehir merkezlerinde ya da köy ve kasabada ikamet ediyor olmak öğrencilerin mizaha yaklaşım tarzlarını çok fazla etkilememiştir. Bu sonuç, mizahın mekân fark etmeksizin insanî bir edim olduğuyla açıklanabilir. Zira mizah insanın olduğu her yerde vardır. Belki ikamet edilen yerin özelliği mizahın türünü ya da içeriğini değiştirebilir; ancak normal koşullarda mizah üretme, mizahı kullanma ve mizah üreten kişilere karşı tutum gibi mizahî edimlerin ikamete göre farklılık oluşturması beklenen bir sonuç değildir.

Illahiyat Fakültesi öğrencilerinin sosyoekonomik düzey bakımından yalnızca mizah üretme alt boyutunda anlamlı bir fark bulunmuştur (Tablo-5). Buna göre sosyoekonomik olarak üst düzeyde bulunan öğrenciler, orta ve alt düzeyde olanlara göre daha yüksek puan almışlardır. Diğer bir ifadeyle sosyoekonomik bakımından üst düzeyde olan öğrencilerle, orta ve alt düzeyde olanlar arasında nüktedan olma, mizahı sıklıkla kullanma ve insanları güldürme yeteneğini temsil eden mizah üretme konusunda anlamlı farklılık vardır. Literatürde benzer sonuçlara rastlanmıştır. Ay ve arkadaşları (2013) tarafından yapılan bir çalışmada kendilerini üst sosyoekonomik düzeyde algılayan öğrenciler, mizahı gündelik hayatında kullanma, ilişkileri kolaylaştırma ve grupta kabul görme gibi amaçlar için kullanmaktadır. Kuzgun (1987) tarafın- 
dan yapılan ve bireyin psikolojik intiyaçlarının bulunduğu sosyoekonomik düzeye göre farklılık gösterip göstermediğini araştıran bir çalışmada alt sosyoekonomik düzeyde bulunanların itaat ve uyum, üst sosyoekonomik düzeyde bulunanların ise bağımsızlık, özerklik, kendine güven, başkalarına hâkim olma, otoriteye ve geleneklere karşı çıkmayla karakterize edilen bir ihtiyaç örüntüsüne sahip oldukları saptanmıştır. Takdir edilir ki, üst sosyoekonomik düzeyde bulunan öğrencilerin karakteristik özellikleri mizah anlayışını çağrıştırmakta ve hatta mizah anlayışına sahip olan kişilerde karşılaşılan kişilik özellikleri arasında yer almaktadır (Thorson \& Powell, 1993c).

Öğrencilerin öğrenim gördükleri sınıfa göre mizah anlayışı alt boyutlarında anlamlı bir farklılık tespit edilememiştir (Tablo-6). Yani sınıflar arası mizaha bakış açısı ve tutum açısından belirgin bir farklılık gözlenmemiştir. Ancak Madhan ve arkadaşlarının (2013) çalışmasında ise 3.,4., ve 5. sınıf ile 1. ve 2. sınıf arasında ve 5. sınıf ile 3. sınıf arasında üst sınıfların daha yüksek puan aldığı, ve bu farkın anlamlılık seviyesine ulaştığı tespit edilmiştir. Araştırmacılar bu durumu Diş Hekimliği Fakültesi öğrencilerinin üst sınıflara doğru ders yoğunluğunun artmasına paralel olarak stresin artması ve öğrencilerin bu stresi yenmek için mizahı başa çıkma olarak kullandıkları için mizah anlayışı puanlarının artmış olabileceği şeklinde yorumlamışlardır.

Son olarak yaş ile mizah anlayışı alt boyutları arasındaki ilişkilere bakıldığında yaş değişkeninin mizah anlayışı alt boyutlarının tamamı ile negatif yönde korelasyona sahip olduğu görülmektedir (Tablo-7). Diğer bir ifadeyle yaş arttıkça mizahla ilgili maddelere verilen puanlar düşme eğilimindedir. Ancak söz konusu korelasyon yalnızca mizahı başa çıkma yolu olarak kullanma alt boyutunda anlamlılık seviyesine ulaşmıştır. Bu sonuca göre, yaş arttıkça öğrencilerin günlük problemleri ve stresi yenme hususunda mizaha daha az başvurdukları söylenebilir. Benzer şekilde Jose ve arkadaşları (2007) mizah anlayışı toplam puanı ile mizah üreten kişilere karşı tutum alt boyutu ile yaş arasında olumsuz ilişki tespit etmiştir.

Sonuç olarak, ilahiyat lisans ve IDKAB öğrencilerinin mizah anlayışları ve dindarlık algıları arasındaki ilişkinin araştırıldığı bu çalışmada İlahiyat Fakültesi öğrencilerinin, gülmeye ve mizaha yönelik olumsuz bir tavır ve tutumda olmadıkları tespit edilmiştir. Araştırma sonuçları, mizah üretme ve mizahı günlük hayatta etkin kullanma hususunda nispeten çekingen olsalar da öğrencilerin mizah üreten kişileri takdir ettiklerini, mizahı onayladıklarını ve mizaha karşı olumlu tutum geliştirdiklerini ortaya koymuştur. Diğer taraftan İlahiyat Fakültesi öğrencilerinin mizah anlayışları ile dindarlık algıları arasında mizaha ve mizahçılara karşı tutum konusunda pozitif yönde anlamlı ilişkilerin olduğu 
görülmüştür. Buradan hareketle, yüksek din eğitimi alan Illahiyat Fakültesi öğrencilerinin mizah konusunda yaratıcı ve üretken olmasalar da, mizaha ilgili duydukları ve mizaha karşı olumlu tutum geliştirdikleri sonucuna varılabilir.

Örneklemin İlahiyat Fakülteleri öğrencilerinden oluşması, bu araştırmanın en önemli sınılıı̆ğıdır. Bundan sonra yapılacak çalışmalarda mizah anlayışı, daha geniş örneklemlerde incelenebilir, farklı bölümlerle karşılaştırmalı çalışmalar yapılabilir ve farkı değişkenlerle olan ilişkileri araştııılabilir. Yapılan bu çalışmanın bir ön çalışma niteliğinde olduğu, bundan sonra araştırma yapacak araştırmacılara ışık tutacağı ve literatüre katkı sağlayacağı umut edilmektedir.

\section{Kaynakça}

Abel, M. H. (2002). Humor, stress, and coping strategies. International Journal of Humor Research, 15(4), 365-381.

Akın, A., ve Bilgin, O. (2015). Çocuklar İçin Çok Boyutlu Mizah Anlayışı Ölçeği'nin Türkçe formu: Geçerlik ve güvenirlik çalışması. Journal of International Social Research, 8(37), 684-688.

Allport, G. W. (1961). Pattern and growth in personality. New York: Holt, Rinehart\&Winston.

Altınay, R. (2004). İslâm mizahının ortaya çıkışı ve ilk örnekleri. Nüsha, 15, (Sayfa Numarası Yok). http://www.doguedebiyati.com/nusha.htm adresinden 9 Nisan 2014 tarihinde edinilmiştir.

Aslan, H. S., Alparslan, Z. N., Evlice, Y. E., Aslan, O., ve Cenkseven, F. (1999). Çok Boyutlu Mizah Duygusu Ölçeği: Faktör yapısı, güvenirlik ve geçerlik çalışması. Psikiyatri Psikoloji Psikofarmakoloji Dergisi, 7(1), 3339.

Avcı, A. (2003). Toplumsal eleştiri söylemi olarak mizah ve gülmece. Birikim, 166, (Sayfa Numarası Yok), http://www.birikimdergisi.com/birikimyazi/3891/toplumsal-elestiri-soylemi-olarak-mizah-ve-gulmece\#.VxTejLBLaY adresinden 4 Mayıs 2014 tarihinde edinilmiştir.

Ay, Ö., Gökler, R. ve Koçak, R. (2013). Mizah tarzları, yaratıclık ve yaşam doyumu: Ortaöğretim öğrencileri üzerinde bir inceleme. International Journal of Social Science, 6(6), 739-767.

Ayten, A., Göcen, G., Sevinç, K. ve Öztürk, E. (2012). Dini başa çıkma, şükür ve hayat memnuniyeti ilişkisi: Hastalar, hasta yakınları ve hastane çalı- 
şanları üzerine amprik bir araştırma. Dinbilimleri Akademik Araştırma Dergisi, 12(2), 45-79.

Bennett, D. J. (2011). The humor of Christ: A different methodological approach. Humor: International Journal of Humor Research, 24(3), 349-356.

Boyle, G. J., \& Joss-Reid, J. M. (2004). Relationship of humor to health: A psychometric investigation. British Journal of Health Psychology, 9, 5166.

Cann, A., Norman, M. A., Welbourne, J. L., \& Calhoun, L. G. (2008). Attachment styles, conflict styles and humour styles: Interrelationships and associations with relationship satisfaction. European Journal of Personality, 22(2), 131-146.

Capps, D. (2006). Religion and humor: Estranged bedfellows. Pastoral Psychology, 54(5), 413-438.

Collicutt J. \& Gray, A. (2012). A merry heart doeth good like a medicine: Humor, religion and wellbeing. Mental Health, Religion \& Culture. 15 (8), 759-778.

Çelik, B. (2014). Dokuzuncu sınıf bilgi ve iletişim teknolojisi dersinde mizah ve kavram karikatürü kullanımının öğrenci başarısı, tutumu, kaygısı ve kalıcılığa etkisi. Yayınlanmamış Yüksek Lisans Tezi. Aydın: Adnan Menderes Üniversitesi, Sosyal Bilimler Ensitütüsü.

Dixon, P., Willingham, W. K., Chandler, C. K., \& McDoughal, K. (1986). Relating social interest and dogmatism to hapiness and sense of humor. Individual Psychology: Journal of Adlerian Therory, Research \& Practice, 42(3), 421-427.

Doğan, Y. (2004). Hz. Peygamber ve mizah. Cumhuriyet Üniversitesi Illahiyat Fakültesi, 8(2), 191-203.

Doğan, Y. (2006). Emeviler döneminde mizahı etkileyen faktörler. İstem, 4(8), 2006, 209-236.

Esterhuyse, K. G., Nortje, N., Pienaar, A., \& Beukes, R. B. (2013). Sense of humour and adolescents' cognitive flexibility. South African Family Practice, 55(1), 90-95.

Freud, S. (2012). Espriler ve bilinçdışı ile ilişkileri, Emre Kapkın (çev.), İstanbul: Payel Yayıncılık.

José, H., Parreira, P., Thorson, J. A., \& Allwardt, D. (2007). A factor-analytic study of the multidimensional sense of humor scale with a Portuguese sample. North American Journal of Psychology, 9(3), 595-610. 
Koenig, H. G., George, L. K., \& Titus, P. (2004). Religion, spirituality, and health in medically ill hospitalized older patients. Journal of the American Geriatrics Society, 52(4), 554-562.

Kuiper, N. A., \& Nicholl, S. (2004). Thoughts of feeling better? Sense of humor and physical health. Humor: International Journal of Humor Research, 17(1/2), 37-66.

Kuzgun, Y. (1987). Sosyo-ekonomik düzey ve psikolojik ihtiyaçlar. Ankara Üniversitesi Eğitim Bilimleri Fakültesi Dergisi, 1-2, 55-68.

Kur'an-ı Kerim Meali (2015). Ankara: Türkiye Diyanet Vakfı Yayınları

Madhan, B., Barik, A. K., Patil, R., Gayathri, H., \& Reddy, M. S. R. (2013). Sense of humor and its association with psychological disturbances among dental students in India. Journal Of Dental Education, 77(10), 1338-1344.

Martin, R. (2007). Psychology of humor: An integrative approach. United States of America: Elsevier Academic Press.

Martin, R., Puhlik-Doris, P., Larsen, G., Gray, J., \& Weir, K. (2003). Individual differences of uses of humor and their relation to psychological wellbeing: Development of Humor Styles Questionarre. Journal of Research in Personality, 37(1), 48-75.

Marzolph, U. (2000). The Qoran and jocular literature. Arabica, 47(3/4), 478487.

Maslow A. (1970). Motivation and Personality, New York: Harper and Row Publishers.

Özgen, G. (2014). Üsküdar bölgesinde görev yapan öğretmenlerin mizah tarzları ve dini başa çıkmaları arasındaki ilişki. Yayınlanmamış yüksek lisans tezi. İstanbul: Marmara Üniversitesi Sosyal Bilimler Ensitütüsü.

Park, C. L. (2005). Religion as a meaning-making framework in coping with life stress. Journal of Social İssues, 61(4), 707-729.

Saroglou, V. (2002a). Beyond dogmatism: The need for closure as releated to religion. Mental Helath, Religion \& Culture, 5(2), 183-194.

Saroglou, V. (2002b). Religion and Five Factors of Personality: A metaanalytic review. Personality and Individual Differences, 32, 15-25.

Saroglou, V. (2002c). Religiousness, religious fundementalism and quest as predictors of humor creation. The International Journal For The Psychology of Religion, 12(3), 177-188. 
Saroglou, V. (2014). Religion, personality, and social behavior. New York: Psychology Press.

Saroglou, V., \& Anciaux, L. (2004). Liking sick humor: Coping styles and religion as predictors. Humor: International Journal of Humor Research, 17(3), 257-277.

Saroglou, V., \& Scariot, C. (2002). Humor Styles Questionnaire: Personality and educational correlates in Belgian high school and college students. European Journal of Personality, 16(1), 43-54.

Savaş, S. (2013). İlköğretim 7. Sınıf Türkçe Derslerinde Mizah Kullanımının Öğrenci Başarısına Etkisi. Karaelmas Eğitim Bilimleri Dergisi, 1(1), 7388.

Schwartz, S. H., \& Huismans, S. E. (1995). Value priorities and religiosity in four western religions. Social Psychology Quarterly, 58, 88-107.

Szabo, A. (2003). The acute effect of humour and exercise on mood and anxiety. Journal of Leisure Research, 35(2), 152-162.

Şahin, O. (2010). Sosyal bilgiler öğretiminde mizah kullanımının öğrencilerin akademik başarılarına ve tutumlarına etkisi. Mehmet Akif Ersoy Üniversitesi Sosyal Bilimler Enstitüsü Dergisi, 2(3), 56-73.

Tariq, Q., \& Khan, N. A. (2013). Relationship of sense of humor and mental health: A coorelational study. Asian Journal of Social Sciences \& Humanities, 2(1), 331-337.

Thorson, J. A., \& Powell, F. C. (1993a). Development and validation of a multidimensional sense of humor scale. Journal of Clinical Psychology, 49, 13-23.

Thorson, J. A., \& Powell, F. C. (1993b). Relationships of death anxiety and sense of humor. Psychological Reports, 72, 1364-1366.

Thorson, J. A., \& Powell, F. C. (1993c). Sense of humor and dimensions of personality. Journal of clinical Psychology, 49(6), 799-809. 


\section{Reviewing the Sense of Humor of Undergraduate Students at Faculty of Divinity in Terms of Some Variables}

Citation / ( - Emre, Y.-Özgen, G. (2017). Reviewing the Sense of Humor of Undergraduate Students at Faculty of Divinity in Terms of Some Variables, Çukurova University Journal of Faculty of Divinity, 17 (1), 277-298.

Abstract- It is thought that the sense of humor and religiosity are irrelevant concepts and therefore in Turkey there aren't enough researches that examine the relationship between these two concepts. A descriptive survey design was utilised to determine the relation between religiosity and sense of humor of undergraduates who are educated at the Faculty of Divinity and to investigate the role of the demographic variables on sense of humor. The data were collected in the academic year of 2014-2015. The sample consisted of 346 undergraduate students from the faculty of divinity and religious culture and moral education at six separate faculties of divinity in Turkey. Multidimensional Sense of Humor Scale which was adapted by Aslan, Alparslan, Evlice, Aslan and cenkseven (1999) was administered to collect the data on sense of humor of participants. According to the results of statistical analyses regarding the sense of humor, age, sex and income level were found to be associated with the sense of humor of the participants, but there was not difference between sense of humor and the grade and residense of the participants. Contrary to relevant researches and literature, results indicated that there was positive correlation between sense of humor and religiosity of the undergradute students.

Keywords- Sense of humor, religiousness, humor, multidimensional sense of humor scale, faculty of divinity 